\title{
Effects of Low Dose Dioxin on Membrane Bound Ion Dependent ATPases in Mice Kidney
}

\author{
${ }^{1}$ Jyoti Jigyasi, ${ }^{2}$ Rahul Kundu \\ ${ }^{1,2}$ Department of Biosciences, Saurashtra University, Rajkot-360005, Gujarat State, India
}

\begin{abstract}
The present communication reports the dose and exposure dependent effects of a dioxin on few ion dependent membrane bound ATPases of mice kidney. Effects of TCDD on the specific activity of few membrane bound ATPases viz., Total ATPase, $\mathrm{Na}^{+} \mathrm{K}^{+}$ATPase, $\mathrm{Ca}^{++}$ATPase, $\mathrm{Mg}^{++}$ATPase, $\mathrm{Ca}^{++}, \mathrm{HCO}_{3}^{-}$ATPase, $\mathrm{Mg}^{++}$, $\mathrm{HCO}_{3}^{-}$ATPase were observed. Two basic hypotheses were tested viz., (a) the sublethal in vivo exposure of $T C D D$ evokes a dose and duration dependent effects on the membrane bound ATPases of the renal cells of mice and (b) TCDD possibly has a direct effect on the membrane bound ATPase system. Two groups were exposed to two sublethal doses $(0.004 \mathrm{mg} / \mathrm{kg} \mathrm{bw} / \mathrm{d}, 0.04 \mathrm{mg} / \mathrm{kg} \mathrm{bw} / \mathrm{d})$ of TCDD by a daily oral administration for 2,4 and 6 days. A separate control group received corn oil for same exposure duration. The results indicated predominant exposure duration dependent alterations in membrane bound ATPases. In conclusion, the results suggested that the membrane bound ATPases were indeed influenced by the TCDD exposure. However, the effects were possibly indirect, by complex chains of reactions exhibited by the cells when subjected to the toxic stress.

Keywords: ATPases, Dose \& Duration dependent toxicity, Kidney, mice, TCDD
\end{abstract}

\section{Introduction}

Living organisms including man may be exposed to persistent organic pollutants that have either dioxin like or non-dioxin like properties such as many PCBs, pesticides and organochlorines [1]. 2,3,7,8 tetra chloro di benzo-p-Dioxin (TCDD) has received considerable attention since its presence in the environment may cause potential human health hazards. Humans are exposed to dioxins primarily through the consumption of food and water on a daily basis and to a lesser extent, by inhalation [2]. Though the toxicity of TCDD has been widely examined in multiple acute, sub chronic and chronic studies [3]. Most studies reported effects of TCDD on the receptor mediated responses or various metabolic activities [4]. ATPases are known to be regulating the ions and metabolites across the plasma membrane in order to maintain the normal physiological and biochemical functions of the cells. TCDD was reported to cause edema by impairing water excretion in the kidney. TCDD was found to cause no apparent effect on $\mathrm{Na}^{+} \mathrm{K}^{+}$ATPase protein levels or localization in low doses [5]. The $\mathrm{Na}^{+}$ $\mathrm{K}^{+}$ATPase dependent membrane bound ion pumps in the tubules generally performs normal ion transport processes [6]. In addition to the alteration in shape, TCDD generally reduce the area of Bowman's space, though the increasing pressure from edema formation might have a flattening effect on the glomerulus [5]. It was reported that TCDD disrupted the water barrier against the inward diffusion of water and thereby increasing the blood vessel permeability in trout larvae [7]. Renal toxicity of dioxin like PCBs occurred due to the inhalation of toxicant, duration dependent oral exposure and dermal contacts. It was reported that 213 days of exposure to 1.5 $\mathrm{mg} / \mathrm{m}^{3}$ dose of Aroclor 1254 caused slight degeneration of the renal tubules [8]. After 24 hours following treatment of Aroclor 1242, by a single near-lethal gavage dose of $4,000 \mathrm{mg} / \mathrm{kg}$, produced renal tubular damage in rats [9]. Aroclor 1254 exposure for 15 weeks with the concentration of $1.0 \mathrm{mg} / \mathrm{kg} / \mathrm{day}$ produce Cortical tubular protein casts in kidney [10]. Going through the literature it was evident that studies are very less on the toxicity of dioxin in renal cell membrane system in general and ATPase system in particular. Hence, in the present study experiments were carries out to estimate the dose and duration dependent toxicity of TCDD to the membrane ATPases of the mice renal tissue. The present study tests two basic hypotheses that (a) the sublethal in vivo exposure of TCDD evokes a dose and duration dependent effects on the membrane bound ATPases of the renal cells of mice and (b) TCDD possibly has a direct effect on the membrane bound ATPase system.

\subsection{Animals}

\section{Materials And Methods}

Adult female Swiss albino mice, around 3 months of age and weighing $30 \pm 5 \mathrm{~g}$, were used for the entire study. The animal groups were provided with ad libitum commercially available rodent diet and water and kept under highly hygienic conditions in the animal house facilities as approved by the CPCSEA, India. The mice were kept under controlled humidity, temperature $\left(25 \pm 2{ }^{\circ} \mathrm{C}\right)$ and diurnal cycle of $14: 10 \mathrm{~h}$. The infected and moribund animals were removed or not included for experimental study. All experiments were conducted according to ethical norms provided by CPCSEA India (CPCSEA/CH/RF/ACK-2003). 


\subsection{Chemicals}

2,3,7,8 TCDD was procured from Sigma- Aldrich chemicals Pvt. Ltd. (CAS No. 1746-01-6). All other chemicals used for this study were of analytical grade.

\subsection{Experimental Design and Treatment}

In the present study, a total of 81 adult female mice were used in different groups. The intoxication was done by oral administration of 2,3,7,8 TCDD (Sigma) in 0.004 and $0.04 \mathrm{mg} / \mathrm{kg}$ body weight/day doses, dissolved in corn oil (Sigma) for three different exposure durations (2, 4 and 6 days). Separate control groups were also maintained that received a similar daily dose of vehicle (corn oil) only. The selection of doses were based on the $\mathrm{LD}_{50}$ of TCDD in mice along with the minimum required dose reported to be toxic to human and the availability of TCDD and its residue in nature.

\subsection{Tissue Preparation and Enzyme Assay}

After toxic exposure, the kidney was quickly harvested and washed in ice cold Sucrose-EDTAImidazole (SEI) buffer. Fixed amount of kidney tissue was homogenized in a Potter-Elvehjem glass homogenizer at $4{ }^{\circ} \mathrm{C}$ in SEI buffer to make a $10 \%(\mathrm{w} / \mathrm{v})$ tissue concentration. Tissue extraction and Enzyme assay of total, $\mathrm{Na}^{+}-\mathrm{K}^{+}, \mathrm{Ca}^{++}, \mathrm{Mg}^{++}, \mathrm{CaHCO}_{3}{ }^{-}$and $\mathrm{MgHCO}_{3}{ }^{-}$ATPases were done by the method of Zaugg [11] with appropriate modifications $[12,4]$. Resulting inorganic phosphate was measured by the method of Fiske and Subbarow [13]. Protein content in the tissue extract was estimated by the method of Lowry et al. [14] using crystalline bovine serum as standard.

\subsection{Statistical Analysis}

The obtained data were subjected to various statistical analyses for their cumulative acceptability and for testing the hypotheses formulated. A single factor ANOVA was employed for the significance in the variations between control and doses. A two-way nested ANOVA test was done to check the significance in the variations between different doses and amongst different exposure durations. In addition to those tests, Student's t-test was employed for the significance in the variations between control and each duration within a given dose. All statistical procedures were done as per Sokal and Rohlf [15].

\section{Results}

In the present study, dose and exposure duration dependent toxicity of TCDD to various membrane bound ion dependent ATPases in mice renal tissue was estimated. Results of the present investigation showed variations in the renal membrane ATPases after exposure to different doses of 2,3,7,8 TCDD. The specific activity of Total ATPase showed inhibition in all exposure durations in lower dose $(0.004 \mathrm{mg} / \mathrm{kg} / \mathrm{d}) \mathrm{group}$. In high dose $(0.04 \mathrm{mg} / \mathrm{kg} / \mathrm{d})$ group, initial inhibition was observed after 2 and 4 days of exposure durations, but stimulation in the specific activity was observed after 6 days of exposure duration (Fig. 1a). In case of $\mathrm{Na}^{+} \mathrm{K}^{+}$ ATPase, the specific activity showed inhibitory trend in all exposure duration in the lower dose $(0.004 \mathrm{mg} / \mathrm{kg} / \mathrm{d})$ group. In case of high dose group, the specific activity was highly inhibited in lower exposure durations but slight stimulation was observed after 6 days of exposure duration (Fig. 1b). The activity of $\mathrm{Ca}^{++}$ATPase in both the dose groups $(0.004 \& 0.04 \mathrm{mg} / \mathrm{kg} / \mathrm{d})$ showed inhibition after 2 and 4 days of exposure durations, whereas, slight stimulation was observed after 6 days of exposure duration (Fig. 1c). However, in case of $\mathrm{Mg}^{++} \mathrm{ATPase}$ the specific activity was initially stimulated after 2 and 6 days of exposure duration, while, inhibition was observed in 4 days of exposure duration in both dose groups (Fig. 1d). The specific activity of $\mathrm{Ca}^{++}, \mathrm{HCO}_{3}{ }^{-}$ ATPase was highly inhibited in the lower dose group. In the higher dose however, the inhibitory effect was observed after 2 and 4 days of exposure while, high stimulation in the enzyme activity was observed after 6 days of exposure (Fig. 1e). In case of $\mathrm{Mg}^{++}, \mathrm{HCO}_{3}^{-}$ATPase, the activity showed inhibition after 2 and 4 days of exposure durations whilst, stimulation was observed after 6 days of exposure duration in both dose group (Fig. 1f).

\section{Discussion}

Low to moderate renal effects have been reported in different animals exposed to lethal or near-lethal levels of 2,3,7,8 -TCDD. Acute exposure to 2,3,7,8-TCDD reported to have caused dilation of the convoluted tubules and Bowman's spaces in rats [16] and epithelial hyperplasia in the renal pelvis in rhesus monkeys [17]. These reports suggest that the observed renal effects in mature animals may be secondary to the general response to 2,3,7,8 -TCDD toxicity with the exception of the epithelial hyperplasia reported in monkeys. The plasma membrane is the first fence that has to be overcome by toxic compounds targeting to the cell. Present study thus, focuses on this aspects and deals with effects of TCDD on the renal membrane bound ATPases. 
In the present study, the specific activity of Total and $\mathrm{Na}^{+}, \mathrm{K}^{+}$ATPase showed progressive dose and duration dependent inhibition after 2 and 4 days of exposure durations but remained more or less unchanged after 6 days of exposure (Fig. 1a \& 1b). A predominant exposure duration dependent effect was observed in the activity of total and $\mathrm{Na}^{+}, \mathrm{K}^{+}$ATPases as evident from the results of two factor ANOVA between control and toxicated groups (Table 1). It was apparent that the increasing dose of TCDD did not bring about significant changes in the activities of any of the ion dependent membrane bound ATPases studied. Results of t-test between control and individual exposure duration showed significant effects after 4 and 6 days of exposure (Table 2). It is evident that significant effects of TCDD in the specific activity of total ATPase occurred with increasing exposure durations. The stimulation of the enzymatic activity observed after TCDD administration in the present study was possibly not due to direct influence of the TCDD with the enzyme protein itself but may be due to chain of reactions occurred in the cytoplasm [18]. Earlier studies reported that the TCDD binds with cytosolic receptor and transported into nucleus for newer protein synthesis [19]. The resultant expression of some gene expression rather than the TCDD directly interacts with lipophilic membrane channel proteins [20]. The t-test between control and total ATPase and $\mathrm{Na}^{+}-\mathrm{K}^{+}$ATPase activity also showed significant differences in longest exposure durations (Table 2). The observed inhibition in the specific activity may not be due to direct influence of the toxicant with the enzyme itself [18], as the lipophilic TCDD may not take the usual route to enter the cell [6]. It is more likely that TCDD directly enters into the cell by dissolving into the plasma membrane [4]. It may also be possible that the observed disturbance in enzymatic activity caused uncontrolled entry of $\mathrm{Na}^{+}$ions into the cell along the concentration gradient through $\mathrm{Na}^{+} / \mathrm{Ca}^{2+}$ exchanger, resulted the water molecules followed along the osmotic gradient [21] causing membrane swelling and rupture [22].

The specific activity of $\mathrm{Ca}^{++}$and $\mathrm{Mg}^{++}$dependent ATPase showed minor variations between the doses and within exposure durations (Fig. 1c \& 1d). However, significant variation was observed in the higher dose and longest duration. A clear exposure duration dependent effect was observed in case of $\mathrm{Ca}^{++}$and $\mathrm{Mg}^{++}$ ATPase. The results of two factor ANOVA between control and toxicated groups did not show any significant variation amongst doses. Significant variations were however, observed within the exposure durations (Table 1). It has also been observed from t-test between control and individual exposure duration that a significant variation was observed in the longer exposure durations in most of the cases (Table 2). It was also noted that observed variations were higher in $\mathrm{Ca}^{++}$ATPase than that of $\mathrm{Mg}^{++}$ATPase. Slight variations in the activity of $\mathrm{Ca}^{++}, \mathrm{HCO}^{-}$ATPase and $\mathrm{Mg}^{++}, \mathrm{HCO}_{3}{ }^{-}$ATPase over their respective controls were also noted (Fig. 1e \& 1f). However, variation was more in $\mathrm{Ca}^{++}, \mathrm{HCO}_{3}^{-}$ATPase like other ATPases. These two enzymes also showed significant exposure duration dependent effect (Table 1). The results of t-test between control and individual exposure duration indicated significant variations in higher doses (Table 2).

The predominant exposure duration dependent disturbances in the specific activities of the $\mathrm{Ca}^{++}$and $\mathrm{Mg}^{++}$ATPases in the present study possibly indicating a disturbances in calcium homeostasis which may affect various cellular functions such as gene expression, necrosis, cell apoptosis [23]. It has been reported that $G$ protein may mediate many of these type of ion channel regulation by stimulating or inhibiting enzymatic activity via phosphorylation pathway and initiate intracellular cascade for increasing of cytosolic $\mathrm{Ca}^{2+}$, leading to activation or inhibition of specific enzymes or opening of ion channels [24]. Calcium extrusion from the cell by plasma membrane $\mathrm{Ca}^{++}$ATPase, as a result of increased intracellular free calcium levels [23,24]. Extrusion of $\mathrm{Ca}^{2+}$ ions by $\mathrm{Ca}^{2+}$ ATPase is thought to be increase the $\mathrm{Na}^{+}$in kidney cells by stimulate the $\mathrm{Na}^{+} / \mathrm{Ca}^{2+}$ exchanger and loss of $\mathrm{K}^{+}$can cause the cell swelling, which ultimately rupture the membrane or change the shape of the cell [4]. The alteration of ion gradients intracellular can trigger a variety of further mechanism. It may be due to the available free molecules of that toxicant stimulate the different receptor which may be responsible for release of intracellular $\mathrm{Ca}^{2+}$ stores. It is also possible that the enzyme might have accumulated in the intracellular space due to the altered membrane permeability or leakage in the affected membrane [25]. TCDD would cause edema by impairing water excretion by the kidney. TCDD or another AhR agonist which impairs the water export system or water barrier system causing edema [5].

TABLE 1. Results of Two-factor ANOVA between control and toxicated groups.

\begin{tabular}{|l|l|l|l|l|l|l|}
\hline & TOTAL & $\mathbf{N a}^{+}, \mathbf{K}^{+}$ & $\mathbf{C a}^{2+}$ & $\mathbf{M g}^{2+}$ & $\mathbf{C a}^{++} \mathbf{H C O}_{3}{ }^{-}$ & $\mathbf{M g}^{++} \mathbf{H C O}_{3}{ }^{-}$ \\
\hline $\begin{array}{l}\text { Amongst } \\
\text { Doses }\end{array}$ & 3.17 & 0.49 & 1.58 & 1.63 & 1.91 & 2.62 \\
\hline $\begin{array}{l}\text { Within } \\
\text { Duration }\end{array}$ & $26.24^{* *}$ & $18.78^{* *}$ & $21.37^{* *}$ & $6.54^{* *}$ & $4.66^{* *}$ & $18.44^{* *}$ \\
\hline
\end{tabular}

*Significance at $\mathrm{P}=0.05(\mathrm{~F}$ crit of $\mathrm{dF} 2,8=3.63$ )

** Significance at $\mathrm{P}=0.05$ ( $\mathrm{F}$ crit of $\mathrm{dF} 8,26=2.59$ ) 
Total ATPase $\square$ control $\square 0.004 \mathrm{~T} 1 \mathbf{\square} 0.04$ T2
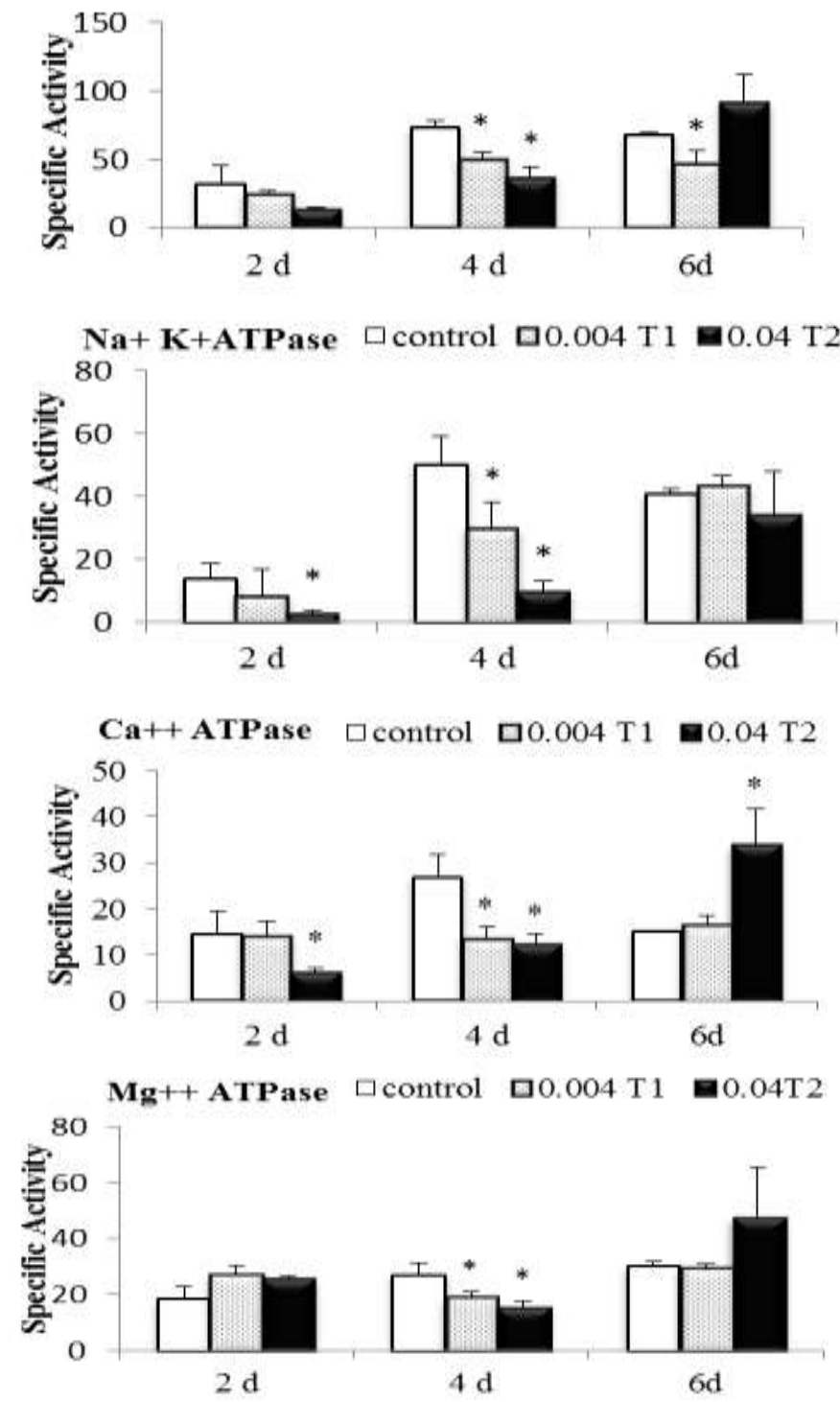

$\mathrm{Ca}^{++} \mathrm{HCO}_{3}^{-}$ATPase $\square$ control $\square 0.004 \mathrm{~T} 1 \mathbf{a} 0.04 \mathrm{~T} 2$

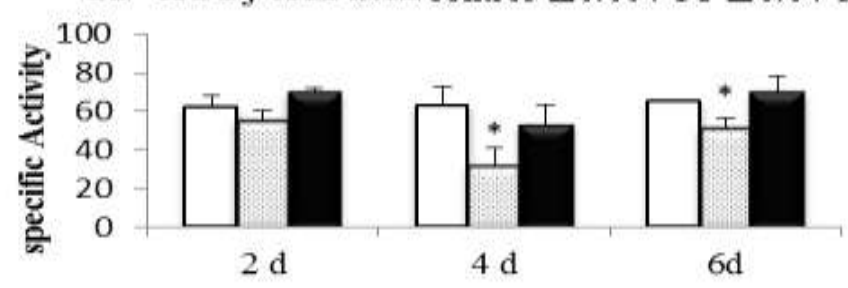

$\underset{250}{\mathrm{MgCO}_{3}-\text { ATPase }} \square$ control $\square 0.004 \mathrm{~T} 1 \mathrm{a} 0.04 \mathrm{~T} 2$

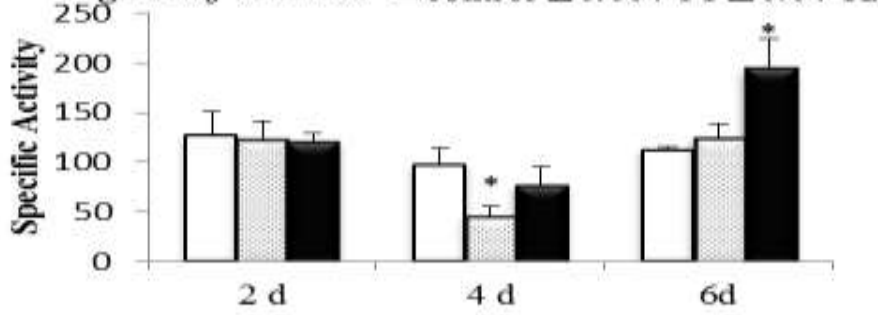

Exposure Duration (in days)

Fig. 1. Dose and duration dependent changes in the specific activities of different ion dependent membrane ATPases after TCDD intoxication. 
TABLE 2. Results of Student's' $t$ '-test between control and individual exposure durations within each dose.

\begin{tabular}{|c|c|c|c|c|c|c|c|c|c|c|c|c|}
\hline & \multicolumn{2}{|c|}{ TOTAL } & \multicolumn{2}{|c|}{$\mathrm{Na}^{+} \mathrm{K}^{+}$} & \multicolumn{2}{|c|}{$\mathrm{Ca}^{2+}$} & \multicolumn{2}{|c|}{$\mathrm{Mg}^{2+}$} & \multicolumn{2}{|c|}{$\mathrm{CaHCO}_{3}^{-}$} & \multicolumn{2}{|c|}{$\mathrm{MgHCO}_{3}^{-}$} \\
\hline & $\begin{array}{l}0.004 \\
\mathrm{mg}\end{array}$ & $\begin{array}{l}0.04 \\
\mathrm{mg}\end{array}$ & $\begin{array}{l}0.004 \\
\mathrm{mg}\end{array}$ & $\begin{array}{l}0.04 \\
\mathrm{mg}\end{array}$ & $\begin{array}{l}0.004 \\
\mathrm{mg}\end{array}$ & $\begin{array}{l}0.04 \\
\mathrm{mg}\end{array}$ & $\begin{array}{l}0.004 \\
\mathrm{mg}\end{array}$ & $\begin{array}{l}0.04 \\
\mathrm{mg}\end{array}$ & $\begin{array}{l}0.004 \\
\mathrm{mg}\end{array}$ & $\begin{array}{l}0.04 \\
\mathrm{mg}\end{array}$ & $\begin{array}{l}0.004 \\
\mathrm{mg}\end{array}$ & $\begin{array}{l}0.04 \\
\mathrm{mg}\end{array}$ \\
\hline 2 days & 0.79 & 2.33 & 1.88 & $\begin{array}{l}4.18 \\
*\end{array}$ & 0.07 & $\begin{array}{l}2.89 \\
*\end{array}$ & 2.59 & 2.64 & 0.71 & 0.82 & 0.19 & 0.10 \\
\hline 4 days & $5.83 *$ & $\begin{array}{l}7.60 \\
*\end{array}$ & $2.88 *$ & $\begin{array}{l}7.33 \\
*\end{array}$ & $4.31 *$ & $\begin{array}{l}4.80 \\
*\end{array}$ & $3.29 *$ & $4.31 *$ & $4.06^{*}$ & 1.26 & $4.80 *$ & 1.47 \\
\hline 6 days & $3.65 *$ & 1.96 & 0.88 & 0.84 & 1.28 & $\begin{array}{l}4.80 \\
*\end{array}$ & 0.72 & 1.62 & $4.56^{*}$ & 0.40 & 1.28 & $\begin{array}{l}4.71 \\
*\end{array}$ \\
\hline
\end{tabular}

*Significance at $\mathrm{P}=0.05$ ( T crit. $=2.77)$

TABLE 3. Results of single-factor ANOVA between individual exposure durations within each group.

\begin{tabular}{|l|l|l|l|l|l|l|}
\hline & TOTAL & $\mathbf{N a}^{+}, \mathbf{K}^{+}$ & $\mathbf{C a}^{2+}$ & $\mathbf{M g}^{2+}$ & $\mathbf{C a H C O}_{\mathbf{3}}^{-}$ & $\mathbf{M g H C O}_{\mathbf{3}}^{-}$ \\
\hline CONTROL & 22.89 & 31.15 & 9.32 & 8.34 & 0.07 & 1.26 \\
\hline 0.004 & $14.09^{*}$ & $29.38^{*}$ & 1.13 & $15.14^{*}$ & $10.11^{*}$ & $26.40^{*}$ \\
\hline 0.04 & $29.94^{*}$ & $11.06^{*}$ & $30.18^{*}$ & $7.15^{*}$ & 1.94 & $24.1^{*}$ \\
\hline
\end{tabular}

*Significance at $\mathrm{P}=0.05(\mathrm{~F}$ crit. $=5.14)$

\section{Conclusion}

The overall results of the present investigation indicating that low dose TCDD had limited effects on the membrane bound ion dependent ATPase. The selected doses were 100 times lower than the $\mathrm{LD}_{50}$ value and hence, produced little changes. TCDD being a lipophilic toxicant possibly did not take the ion channels for entering into the cell. However, statistically significant changes were evident in different exposure durations. This trend was possibly indicating an indirect effect of low dose TCDD on the membrane ATPase system and answers the hypotheses where predominant exposure duration dependent effects were observed. It was also evident that observed effects were possibly indirect through a series of events after the TCDD entered into the cell. However, how TCDD actually affects the membrane bound ATPase system is not clear at this point. The study also raises few questions about how TCDD, a hormone mimicking compound, reacts when inside the cell. It may associate with receptors evoking appropriate responses. However, TCDD which remains free and unattached with receptors in the cytosol may react with other compounds around and evoke responses which may disturb, among others, the membrane transport mechanisms.

\section{Acknowledgement}

Authors are thankful to UGC, Govt. of India, New Delhi, for supporting this study through its DSA / CAS Programme. UGC is also thankfully acknowledged for a Meritorious Research Fellowship to the senior author.

\section{References}

[1] Watanabe S, Kitamura K, Nagahashi M, Effects of dioxins on human health: A review. Journal of Epidemiology, 9, 1999, 1-13.

[2] Mandal P.K, Dioxin: a review of its environmental effects and its aryl hydrocarbon receptor biology. Journal of comparative physiology B Biochemical systemic and environmental Physiologyl, 175, 2005, 221-230.

[3] Kociba R.J, Schwetz B.A, Toxicity of 2,3,7,8 Tetra chloro- di- benzo -p- dioxin. Drug metabolites, 13,1982, 387-406.

[4] Pathak S, Kundu R, Short-term PCB (Aroclor 1254) toxicity on few phosphatases in mice brain. Dose. Response, Published online on 10Feb2011. (http://doseresponse.metapress.com/openurl.asp?genre=article\&id=doi:10.2203/dose-response.10-037.Kundu).

[5] Adrian j Hill, Susan M Bello, Amy L Praseh, Richard E Peterson, warren Heideman, Water permeability and TCDD induced edema in Zebrafish early life stages. Toxicological Sciences 78, 2003, 78-87.

[6] Drummond I.A, Majumdar A, Hentschel H, Elger M, Solnica-Krezel L, Schier AF, Neuhauss SC, Stemple DL, Zwartkruis F, Rangini Z, Driever W, Fishman M.C, Early-V development of the zebrafish pronephros and analysis of mutations affecting pronephric function. Development 125, 1998, 4655-4667.

[7] Guiney P.D, Walker M.K, Spitsbergen J.M, Peterson R.E, Hemodynamic dysfunction and cytochrome P4501A mRNA expression induced by 2,3,7,8-tetrachlorodibenzo-p-dioxin during embryonic stages of lake trout development, Toxicology and Applied Pharmacology 168, 2000, 1-14.

[8] Treon J.F, Cleveland F.P, Cappel J, Atchley RW, The toxicity of the vapors of Aroclor 1242® and Aroclor 1254®. American Industrial Hygiene Association Q 17,1956, 204-213.

[9] Bruckner J.V, Khanna K.L, Cornish HH, Biological responses of the rat to polychlorinated biphenyls. Toxicology and Applied Pharmacology 24, 1973, 434-448.

[10] Gray L.E, Ostby J, Marshalln R, Andrew J, Reproductive and thyroid effects of low level polychlorinated biphenyl (Aroclor 1254) exposure, Fundamental and Applied Toxicology, 20, 1993,288-294.

[11] Zaugg W.S A simplified preparation for ATPase determination in gill tissue. Canadian Journal of Fisheries and Aquatic Sciences, $39,1982,215-217$.

[12] Lakshmi R, Kundu R, Thomas E, Mansuri A.P, Mercuric chloride induced inhibition of different ATPases in the intestine of mudskipper, Boleophthalmus dentatus. Ecotoxicology and. Environmental. Safety, 21, 1991, 121 - 125.

[13] Fiske C.F, Subbarow Y, The colorimetric determination of phosphorus. Journal of Biological Chemistry, 66, 1925, 375-400. 
[14] Lowry O.H, Rosebrough N.J, Farr A.L, Randall R.J, Protein measurement with the Folin-phenol reagent. Journal of Biological Chemistry, 193,1951, 265-275.

[15] Sokal R.R, Rohlf F.J, Biometry. W.H. Freeman and Company. San Francisco, 1969, 260.

[16] Christian B.J, Inhorn S.L, Peterson R.E ,Relationship of the wasting syndrome to lethality in rats treated with 2,3,7,8tetrachlorodibenzo-p-dioxin. Toxicology and Applied Pharmacology, 82,1986a,239-255.

[17] McConnell E.E, Moore J.A, Dalgard D.W,Toxicity of 2,3,7,8-tetrachlorodibenzo-p-dioxin in rhesus monkeys (Macaca mulatta) following a single oral dose. Toxicology and Applied Pharmacology 43,1978, 175-187.

[18] Peterson R.E, Madhukar B.V, Yang K.H, Matsumura F, Depression of adenosine triphosphatase activities in isolated liver surface membranes of 2,3,7,8 tetrachloro dibenzo-p-dioxin in, Khan MAQ, Stanton RH 9eds, Toxicology of halogenated hydrocarbons, Health and ecological effects, Pergamon Press. New York, 1979, 133-145.

[19] Poland A, Kinde A, 2,3,7,8 Tetrachlorodibenzo-p-dioxin environmental contaminants and molecular probe. Federation Proceedings, 35,1976, 2404-2411.

[20] Nebert D.W Genetic differences in the induction of monooxygenase activities by polycyclic aromatic compounds. Pharmacology and Therapeutics, 6, 1979, 395-417.

[21] Thaker J, Chhaya J, Nuzhat S, Mitral R, Mansuri AP, Kundu R, Effects of Chromium (VI) on some ion dependent ATPases in gills, kidney and intestine of a coastal teleost, Periophthalmus dipes. Toxicology, 112, 1996, 237-244.

[22] Kundu R, Lakshmi R, Mansuri AP, The entry of mercury through the membrane: An enzymological study using a tolerant fish Boleophthalmus dentatus. Proceedings of the Acadamics Environmental Biology 1,1992, 1-6.

[23] Kodavanti PRS Intracellular signaling and developmental neurotoxicity. In Molecular Neurotoxicology: Environmental Agents and Transcription-Transduction Coupling. (N. H. Zawia, Ed), 2004, 151-182, CRC Press, Boca Raton, FL.

[24] Kodavanti PRS, Ward TR Differential effects of commercialpolybrominated diphenyl ether and polychlorinated biphenyl mixtures on intracellular signalling in rat brain in vitro. Toxicological Sciences 85, 2005, 952-962.

[25] Suzuki Y, Reduction of hexavalent chromium by ascorbic acid in rat lung lavage fluid. Arch. Toxicology, 62, 1988, 116-122. 